\title{
Wheat Stripe Rust Virulence and Varietal Resistance in the Foot Hill Himalayas of Nepal
}

\author{
Sarala Sharma ${ }^{1}$, Etienne Duveiller ${ }^{2}$, Chandra Bahadur Karki ${ }^{1}$, Dhruba Bahadur Thapa ${ }^{3}$, Ram Chandra Sharma ${ }^{4}$ \\ and Arun Kumar Joshi ${ }^{5}$ \\ 1. Plant Pathology Division, Nepal Agricultural Research Council, Lalitpur 44700, Nepal \\ 2. CIMMYT, Global Wheat Program, Apdo Postal 6-641, Mexico 06600, DF, Mexico \\ 3. Agriculture Botany Division, Nepal Agricultural Research Council, Lalitpur 44700, Nepal \\ 4. ICARDA, Central Asia and the Caucasus Regional Program, Tashkent 10000, Uzbekistan \\ 5. CIMMYT South Asia Regional Office, Kathmandu 44600, Nepal
}

\begin{abstract}
Stripe rust, caused by Puccinia striiformis f. sp. tritici (Pst) is an important disease of wheat (Triticum aestivum) in Nepal, which is a part of the Himalayas stretching over the North of Nepal, India, Pakistan, Bhutan and beyond. Wheat production plays a crucial role in food security of the marginal hill farmers of Nepal. Frequent epidemics of the rust have caused huge loss in farmer's field. Periodic monitoring during 1980-2008 showed that changes in virulence occurred during this period. The objective of this study was to evaluate Pst resistance and its effective genes in wheat genotypes. For this, trap nurseries, wheat stripe rust differentials, commercial cultivars and advanced breeding lines were tested under artificial epiphytotic and natural hot spots conditions during 2005 to 2010. Four genes (Yr5, Yr10, Yr15 and YrSp) consistently showed resistance to the prevailing races. The gene Yr9 and Yr27 in combinations with $\operatorname{Yr} 18$ were found effective. Other lines with combination of minor genes were also found effective. The genotypes Amadina, Kukuna, Tukuru, Kakatsi and Buck Buck widely used in breeding program were resistant. The cultivation of varieties WK1204, Gautam, Gaura and Dhaulagiri have ensured genetic diversity for the rust resistance and slowed down frequent occurrence of epidemics. The findings of these studies could help in developing effective varietal resistance program in the sub-continent.
\end{abstract}

Key words: Puccinia striiformis, resistance, virulence, stripe rust, Triticum aestivum, wheat.

\section{Introduction}

Stripe rust caused by Puccinia striiformis West. $\mathrm{f}$. sp. tritici Eriks. \& Henn. (Pst) has posed a great threat to wheat (Triticum aestivum L.) cultivation in South [1, 2], West [3] and Central Asia [4]. The farmers of mid and high hills in Nepal had been facing significant wheat yield losses due to rust and sometimes abandoned the crop when the rust occurred at seedling stage [5]. The wheat agro-ecosystem in Nepal is broadly divided into lowlands (Terai), foothills including valleys, mid-hills and high hills. Wheat is grown all the ways from $60 \mathrm{~m}$ up to $3,000 \mathrm{~m}$ above the sea level that is from warm subtropical to

Corresponding author: Sarala Sharma, senior scientist (S-4), research field: plant pathology. temperate climates. The lowland of Nepal is a part of the vast Eastern Gangetic Plains (EGP) in South Asia, whereas mid hills and high hills mountains are continuum of the Himalayas in the sub-continent. Due to climatic diversity in Nepal, wheat crop is grown in the field throughout the year [6], and thus presents a unique set of environments favouring survival and development of the rust. The seriousness of wheat stripe rust in the hills is reflected through several epidemics of the rust in Nepal in the past 25 years [5]. High humidity caused by heavy dew in the winter months and cool temperatures during spring season creates conducive environment for frequent outbreak of the rust in the hills and high hills, and occasionally in the lowlands [7]. Epidemics of the rust in 
Sindhupalchok and Dolakha districts in Nepal during 1980s were mainly due to summer wheat grown in that region [6] and the cultivation of a single cultivar RR21 in more than $70 \%$ of the area year after year. The rust developed and produced abundant inoculum in the summer wheat for the next normal season (November-June) wheat crop. Summer wheat acts as a bridge for the rust to the normal season wheat, and so epidemics of the rust in the normal season wheat was experienced in the hills during 80s and 90s [8,9].

Studies done at Agricultural Research Farm, Kavre have shown $30 \%$ and $15 \%$ reductions, respectively, in wheat grain yield and 1,000-kernel weight (TKW), due to the rust [10]. The maximum loss was recorded on Morocco at both Kavre and Khumaltar. There was no grain formation at Kavre and there was as much as 95\% grain yield loss at Khumaltar [6]. Several stripe rust resistant lines developed by the International Maize and Wheat Improvement Center (CIMMYT) and the national programs, like Annapurna-1, Annapurna-3, Annapurna-4 and Kanti, were deployed for Nepal hills. However, these varieties showed poor adoption by farmers [5] and became susceptible when Yr9 virulent race appeared. Some varieties like BL1473 had wider coverage in Kathmandu valley, but became susceptible to the rust due to occurrence of a new race [5]. During 2000-2004, there was relatively lesser incidence of the rust due to wider coverage of the resistant cultivar Nepal 297. Due to lack of farmers' preferred criteria in the new cultivar, the varietal replacement in the hills of Nepal was slow, resulting in growing the same old cultivars RR21 and Nepal 297 till the end of the 20th century [11] and until the early years of this century, resepectively [5]. Inoculum source from susceptible cultivars, congenial environment, less genetic diversity and occurrence of virulent race resulted in epidemics during the 2004-2007 wheat growing seasons [12]. Hence, the present study was conducted to identify effective stripe rust resistant genes and lines/cultivars against new stripe rust races, and minimize wheat yield losses faced by hill farmers of Nepal.

\section{Materials and Methods}

Five studies were conducted using stripe rust differentials, commercial cultivars and advanced breeding lines from various sources. Seeds of the stripe rust wheat differentials were obtained from the International Center for Agriculture Research in the Dry Areas (ICARDA), Syria, CIMMYT, Mexico, the DLO Research Institutes for Plant Protection, the Netherlands (IPO-DLO) and the Plant Breeding Institute, Sydney, Australia. Seeds of the wheat commercial varieties and advanced breeding lines for seedling and adult plant resistance tests were obtained from the National Wheat Research Programs, Bhairahawa and Agriculture Botany Division, Khumaltar, Lalitpur. The senior author scored the rust severity and reactions in all experiments. Three trap nurseries were evaluated at Khumaltar Research Station, Lalitpur and in farmers' fields at Ramkot, Kathmandu valley. International differential sets of wheat lines containing known stripe rust resistance genes were also evaluated, and elite lines and cultivars were screened under heavy epiphytotic conditions. The scoring was performed by using modified Cobb’s scale, where resistant is considered as " $R$ ", moderate resistant as "MR", moderately susceptible as "MS" and susceptible as " $\mathrm{S}$ ". $\mathrm{R}$ is considered as visible chlorosis, no uredia present. MR is small uredia present and surrounded either by chlorosis or necrosis. MS is medium sized uredia present and surrounded by chlorotic area. $\mathrm{S}$ is large uredia present with no chlorosis or necrosis.

\subsection{Effective Stripe Rust Resistance Genes Evaluation Using Near-Isolines (NILs) Set}

A set of 19 Avocet NILs set received from Plant Breeding Institute, the University of Sydney, Australia was planted at Khumaltar $\left(27.65^{\circ} \mathrm{N}, 85.02^{\circ} \mathrm{E}, 1,369\right.$ $\mathrm{m}$ above the sea level) in rod row design of $2 \mathrm{~m}$ length with $0.25 \mathrm{~m}$ row to row spacing. 


\subsection{Monitoring Yellow Rust Resistant Genes Using International Yellow Rust Trap Nursery (IYRTN)}

The IYRTN containing 50 wheat lines was planted at Ramkot during $2007-2008\left(27.43^{\circ} \mathrm{N}\right.$ and $\left.85.15^{\circ} \mathrm{E}\right)$ and Khumaltar during 2007-2009.

2.3 Monitoring Different Promising Wheat Lines and Commercial Cultivars in International Disease Trap Nursery (IDTN)

Likewise, IDTN containing 110 wheat lines was evaluated at Khumaltar during 2006-2010 wheat seasons planting in simple two rows of $1.5 \mathrm{~m}$ long at $0.25 \mathrm{~m}$ row spacing.

2.4 Virulence and Avirulence Analysis of Stripe Rust between 2005 and 2006

The international wheat stripe rust differential set (20 lines) composed at IPO-DLO, the Netherlands were evaluated at Khumaltar in 2005 and 2006 wheat seasons using two rows of $1.5 \mathrm{~m}$ long planted at 0.25 $\mathrm{m}$ row spacing. Virulence and avirulence reaction types were recorded as the methods described by Danial and Broers [13].

\subsection{Evaluation of Wheat Lines/Cultivars for Stripe Rust Resistance}

Screening of advanced wheat breeding lines from the Wheat Research Improvement Program in Nepal and CIMMYT was done at Khumaltar under artificial epiphytotic condition. Individual plot size was $0.75 \mathrm{~m}^{2}$ consisting of two rows of $1.5 \mathrm{~m}$ long at $25 \mathrm{~cm}$ row to row spacing. Two rows of susceptible varieties (Agra local, Morocco and WK594) were planted as border, while the susceptible check Morocco variety was planted every after the 10th entry. Two-week-old seedlings of Morocco grown in pots were inoculated and covered with polythene sheets and kept inside the polyhouse at $9{ }^{\circ} \mathrm{C}$. Inoculated plants were checked for the rust after two weeks of inoculation, and the spores were collected when the plants showed high production of spores. Spore suspension was made in distilled water with one drop of Tween 20. Inoculation was done by spraying using Ulva sprayer. Disease scores on adult plants were recorded using the modified Cobb's scale. $\mathrm{Yr}$ genes in the cultivars and the differential lines were mentioned based on gene postulation done at IPO-DLO [14] and the field book of IYRTN compiled by ICARDA as well as Louwers et al. [15].

\section{Results and Discussion}

\subsection{Effective Stripe Rust Resistance Genes Evaluation Using NILs Set}

Host reaction and stripe rust severity differed for different $Y r$ genes in different years (Table 1). Stripe rust resistance genes $\operatorname{Yr} 1, \operatorname{Yr} 6, \operatorname{Yr} 7, \operatorname{Yr} 8, \operatorname{Yr} 9, \operatorname{Yr} 17$, Yr18, Yr27 and Yr32 were ineffective against the prevalent races. Similarly, Yr24 and Yr26 showed variation in reactions and severities in the tested years with usually resistant to moderately susceptible reactions. However, some genes ( $\operatorname{Yr} 5, \operatorname{Yr} 10, \operatorname{Yr} 15$ and $\mathrm{YrSp}$ ) consistently showed resistant reactions in all tested years.

\subsection{Monitoring Yellow Rust Resistant Genes Using IYRTN}

The majority of lines in the nursery showed resistant to moderately resistant reactions in 2007-2009 at both sites (Table 2). The lines with different $\mathrm{Yr}$ gene combinations, such as Opata 85 $(Y r 27+Y r 18)$, Super Kauz $(Y r 9+Y r 27+Y r 18)$, Pastor (Yr31 + APR), Vilmorin 23 (w; Yr3a, 4a + other) and Moro (w; Yr10), were resistant in all testing years (Table 3). Anza though has two genes including Yr18, showed moderate infection. Susceptible cultivar Morocco had high score of the rust during the test years, while Kalyansona also showed susceptible reaction [9].

\subsection{Monitoring Different Promising Wheat Lines and Commercial Cultivars in IDTN}

Fifteen of the 110 lines in the IDTN showed resistant reactions to the rust in all five years (Table 3). Opata 
Table 1 Stripe rust severities and reactions on NILs, Australia recorded at Khumaltar, Nepal during 2005-2010 wheat seasons.



MS = moderately susceptible; $\mathrm{MR}$ = moderately resistant; $\mathrm{TR}$ = trace resistance; $\mathrm{R}$ = resistant, - = data not available. 
Table 3 Stripe rust severities and reactions recorded on wheat genotypes in the IDTN at Khumaltar, Nepal during 2006-2010.

\begin{tabular}{|c|c|c|c|c|c|}
\hline \multirow{2}{*}{ Genotype/pedigree } & \multicolumn{5}{|c|}{ Stripe rust severity and host reaction } \\
\hline & 2006 & 2007 & 2008 & 2009 & 2010 \\
\hline CS2D-2M & $10 \mathrm{R}$ & 40MR & $\mathrm{R}$ & $40 \mathrm{MS}$ & 5MR \\
\hline TC*6/P158548 (RL6058) & $5 \mathrm{MR}$ & $20 \mathrm{R}$ & $10 \mathrm{R}$ & $10 \mathrm{MS}$ & $10 \mathrm{MR}$ \\
\hline RL5711 & $10 \mathrm{R}$ & 40MS & $10 \mathrm{R}$ & $40 \mathrm{MS}$ & 40MS \\
\hline Noroeste & 40MS & 40MR-MS & $10 \mathrm{R}$ & $80 \mathrm{~S}$ & 40MS-S \\
\hline Jupateco 73R & $40 \mathrm{R}$ & 20MR & $\mathrm{R}$ & $20 \mathrm{R}$ & $20 \mathrm{MR}$ \\
\hline Anahuac 75 & $40 \mathrm{R}$ & 40MR & $10 \mathrm{MR}$ & $40 \mathrm{R}$ & 40MR \\
\hline Genaro 81 & $20 \mathrm{R}$ & 20MR & $\mathrm{R}$ & $\mathrm{R}$ & $20 \mathrm{MR}$ \\
\hline Seri 82 & $10 \mathrm{R}$ & 40MR & $\mathrm{R}$ & $\mathrm{R}$ & $10 \mathrm{MR}$ \\
\hline Babax \# 2 & $30 \mathrm{R}$ & 40MR & $20 \mathrm{MR}$ & $\mathrm{R}$ & $20 \mathrm{MR}$ \\
\hline Tonichi 81 & 20R & 20MR & $10 \mathrm{MR}$ & $\mathrm{R}$ & $20 \mathrm{MR}$ \\
\hline Parula & $20 \mathrm{R}$ & 40MR & $10 \mathrm{MR}$ & $20 \mathrm{MR}$ & $20 \mathrm{MR}$ \\
\hline Pavon 76 & 60MS-S & 40MS-S & 60MS-S & $20 \mathrm{MR}$ & 20MR \\
\hline Attila (CM85836-50Y-0M-0Y-3M-0Y) & $10 \mathrm{R}$ & $10 \mathrm{MR}$ & $10 \mathrm{MR}$ & $\mathrm{R}$ & $10 \mathrm{MR}$ \\
\hline Amadina (CRG682-8Y-3B-3Y-2B-0Y-0Y) & 20R & $\mathrm{R}$ & $\mathrm{R}$ & $\mathrm{R}$ & $\mathrm{R}$ \\
\hline Buck Buck & $10 \mathrm{R}$ & $\mathrm{R}$ & $\mathrm{R}$ & $\mathrm{R}$ & $\mathrm{R}$ \\
\hline Chapio $=$ CAR422/ANA/YACO/3/KAUZ $* 2 / \mathrm{TRAP} / / \mathrm{KAUZ}$ & $\mathrm{R}$ & $10 \mathrm{R}$ & $\mathrm{R}$ & $\mathrm{R}$ & $\mathrm{R}$ \\
\hline Tukuru = TRAP\#1/YACO/3/KAUZ*2/TRAP//KAUZ & $\mathrm{R}$ & $10 \mathrm{R}$ & $\mathrm{R}$ & $\mathrm{R}$ & 20MR \\
\hline Kukuna = NI/PBW65/3/KAUZ*2/TRAP//KAUZ & $\mathrm{R}$ & $\mathrm{R}$ & $\mathrm{R}$ & $10 \mathrm{R}$ & $10 \mathrm{MR}$ \\
\hline Kakatsi $=$ VN/YACO/3/KAUZ*2/TRAP//KAUZ & $\mathrm{R}$ & $\mathrm{R}$ & $\mathrm{R}$ & $\mathrm{R}$ & $\mathrm{R}$ \\
\hline Morocco & $100 \mathrm{~S}$ & $80 \mathrm{~S}$ & $60 \mathrm{~S}$ & $80 \mathrm{~S}$ & $80 \mathrm{~S}$ \\
\hline PBW343 & $\mathrm{R}$ & $\mathrm{R}$ & $\mathrm{R}$ & $\mathrm{R}$ & $20 \mathrm{MR}$ \\
\hline PBW373 & $\mathrm{R}$ & $\mathrm{R}$ & $\mathrm{R}$ & $\mathrm{R}$ & $\mathrm{R}$ \\
\hline RAJ3765 & $\mathrm{R}$ & $\mathrm{R}$ & $\mathrm{R}$ & $\mathrm{R}$ & $\mathrm{R}$ \\
\hline WL1562 & $20 \mathrm{R}$ & $10 \mathrm{R}$ & $\mathrm{R}$ & $\mathrm{R}$ & $\mathrm{R}$ \\
\hline Bhrikuti & $\mathrm{R}$ & $10 \mathrm{R}$ & $10 \mathrm{MR}$ & $\mathrm{R}$ & $\mathrm{R}$ \\
\hline Inquilab & $40 \mathrm{R}$ & $40 \mathrm{R}$ & $10 \mathrm{MS}$ & $\mathrm{R}$ & $\mathrm{R}$ \\
\hline Bakhtawar & $10 \mathrm{R}$ & $\mathrm{R}$ & $\mathrm{R}$ & $40 \mathrm{MS}$ & $\mathrm{R}$ \\
\hline Kohistan 97 & $80 \mathrm{~S}$ & $80 \mathrm{~S}$ & 20MS & $\mathrm{R}$ & $\mathrm{R}$ \\
\hline Punjab 85 & $60 \mathrm{~S}$ & $60 \mathrm{~S}$ & $10 \mathrm{R}$ & $60 \mathrm{MS}$ & $\mathrm{R}$ \\
\hline Kanchan & $40 \mathrm{R}$ & $60 \mathrm{~S}$ & $10 \mathrm{MR}$ & $60 \mathrm{MS}$ & $60 \mathrm{MS}$ \\
\hline Gaurab & 40MS & $10 \mathrm{R}$ & $\mathrm{R}$ & $\mathrm{R}$ & $10 \mathrm{MR}$ \\
\hline
\end{tabular}

MS = moderately susceptible; MR = moderately resistant; $\mathrm{R}=$ resistant.

85, Jupateco R, Genaro 81, Seri 82, Super Kauz, Babax 2, Tonichi 81, Parula and Buck Buck were resistant, whereas Pavon 76 was moderately susceptible. Other lines, like Amadina, Kukuna, Kakatsi and PBW343 (Yr27), also showed resistant reactions. The widely grown cultivar of Nepal, Bhrikuti and Inqalab of Pakistan mostly showed resistant to moderately resistant reactions.

3.4 Virulence and Avirulence Analysis of Stripe Rust between 2005 and 2006

Out of 19 differential lines, Clement (Yr9), Triticum spelta-album (Yr5), Hybrid 46 (Yr4+), Reichersberg $42(\mathrm{Yr} 7+)$, Heines Peko (Yr6+), Compair $(\mathrm{Yr} 8+)$, Spaldings Prolific (Yrsp) and Heines V11 (Yr2+) showed resistant reactions in both years. The pathotype had virulence to $\operatorname{Yr} 1, \mathrm{Yr} 7, \mathrm{Yr} 6$, SU and CV. It is avirulent to $\mathrm{Yr} 3+, \mathrm{Yr} 10^{+}, \mathrm{YrSd}, \mathrm{Yr9} 9, \mathrm{Yr} 5+$, $\mathrm{Yr} 4+, \mathrm{Yr}^{+}, \mathrm{Yr} 3 \mathrm{~N}, \mathrm{Yr} 8+, \mathrm{YrSp}, \mathrm{Yr} 2+$ and $\mathrm{Yr} 7+$. Present race was different than previous, so Hybrid 46, Heines Peko, Compiar and Heines VII showed susceptible reactions during 80s-90s, indicating a variation in virulence during these 2005 and 2006 years (Table 4). This race is quite different from the 
previous ones. It was highly virulent to $\operatorname{Yr} 27$ and Carsten V.

\subsection{Evaluation of Wheat Lines/Cultivars for Stripe Rust Resistance}

Long-term monitoring study showed differences in stripe rust severity on a set of cultivar known to possess major genes (Table 5). The two cultivars BL1473 and Nepal 297 possessing Yr2 showed higher rust severity in 2006, 2007 and 2008. Among 22 commercial varieties and advanced breeding lines from Nepal, WK1123, WK1182, BL2739, BL2879 and WK1504 were resistant to the rust in all four years (Table 5). The pipeline variety BL3503 showed moderately resistant to moderately susceptible reactions, while BL3235 showed no infection at all. The wheat lines with $\operatorname{Yr} 9$ and additional genes, like Annapurna-1 and BL1022, showed low rust scores. They showed susceptible reactions earlier, probably due to prevalence of new Yr27 virulent race. They may be useful for release and also for breeding purpose.

Table 4 Stripe rust virulence factors to $\mathrm{Yr}$ resistance in the differential set from IPO-DLO in 2005 and 2006.

\begin{tabular}{lll}
\hline Year & Virulence factor $^{1}$ & No. of virulence factors \\
\hline 2005 & $1,7,6+$, SU, CV $($ Yr32) & 5 \\
2006 & 1, SU, CV $($ Yr32 $)$ & 3 \\
\hline
\end{tabular}

${ }^{1}$ Refers to resistant genes in the differential cultivar: Yr1 in Chinese 166, 7 in Lee 6 in H. Kolben, SU in Suwon/Omar, CV in Carstens V according to Danial and Broers [13] and Louwers et al. [15].

Table 5 Responses of commercial cultivars and advanced wheat breeding lines from Nepal tested against prevalent races of stripe rust at Khumaltar, Nepal, during 2005-2008.

\begin{tabular}{|c|c|c|c|c|c|}
\hline \multirow{2}{*}{ Cultivars } & \multirow{2}{*}{ Pedigree } & \multicolumn{4}{|c|}{ Stripe rust score } \\
\hline & & 2005 & 2006 & 2007 & 2008 \\
\hline Gautam & Siddhartha/Ning/8319/NL297 & $10 \mathrm{R}$ & $10 \mathrm{R}$ & $10 \mathrm{R}$ & 20MR \\
\hline Pasang Lhamu & Papago/Seri & TR & $10 \mathrm{R}$ & $10 \mathrm{R}$ & 0 \\
\hline Annapurna-1 & KVZ/BUHO/KAL/BB & TR & 40MR & $10 \mathrm{R}$ & $10 \mathrm{MR}$ \\
\hline Annapurna-4 & KVZ/3/CC/INIA/CNO/ELGAU/4/SN64 & 40MS & 40MS & $40 \mathrm{~S}$ & $60 \mathrm{MS}$ \\
\hline Nepal 297 & HD 2137/HD 2186/HD 2160 & $60 \mathrm{~S}$ & $80 \mathrm{~S}$ & $80 \mathrm{~S}$ & $80 \mathrm{~S}$ \\
\hline BL1473 & Nepal 297/NL352 & $60 \mathrm{MS}$ & 40MS & $60 \mathrm{~S}$ & 20MS \\
\hline WK1204 & SW89.3064/STAR & $10 \mathrm{R}$ & $10 \mathrm{R}$ & $10 \mathrm{R}$ & $20 \mathrm{MR}$ \\
\hline BL3503 & BL1961/NL867 & - & - & $20 \mathrm{MR}$ & $20 \mathrm{MR}$ \\
\hline BL3235 & NL872/NL868 & - & - & TR & 0 \\
\hline BL1022 & PVN/BUC & $10 \mathrm{MS}$ & 10MS & 10MS & $10 \mathrm{MS}$ \\
\hline \multicolumn{6}{|l|}{ Advanced lines } \\
\hline WK1123 & 87Zhong215/WK686 & TR & TR & $\mathrm{TR}$ & TR \\
\hline BL2089 & NL297*2//Danial88/HLB25 & $10 \mathrm{R}$ & $10 \mathrm{R}$ & 40MS & 40MS \\
\hline WK1320 & 87Zhong212/WK685 & $20 \mathrm{R}$ & 40MS-S & 40MR-MS & 30MS \\
\hline WK1182 & CMH25.2578/WK685 & TR & $10 \mathrm{R}$ & $10 \mathrm{R}$ & TR \\
\hline WK1156 & 87Zhong215/WK686 & $\mathrm{TR}$ & TR & TR-40MS & TR-20MS \\
\hline BL2739 & BL1473/NL765 & $20 \mathrm{R}$ & 10MR & $10 \mathrm{R}$ & 0 \\
\hline BL2879 & LGP71AB(WG)/NL759//NL781 & $\mathrm{TR}$ & TR & $10 \mathrm{R}$ & 0 \\
\hline WK1504 & 3BW27/G4M-1M-6;4-3-2-1-1-2//RR21 & $10 \mathrm{R}$ & $10 \mathrm{R}$ & $10 \mathrm{R}$ & $10 \mathrm{R}$ \\
\hline WK1023 & SDY/ALD/3/NAI60/HNC7//BUC/4/Alucan & 20MR-40MS & TR-40R & $20 \mathrm{MR}$ & 20MR \\
\hline WK1444 & Bhrikuti/Simal4058 & $20 \mathrm{R}$ & 20MR & $10 \mathrm{R}$ & 20MS \\
\hline WK936 & Sincron/F287x11F285N & 20MR-MS & TR & 20MR-5MS & 20MR \\
\hline \multicolumn{6}{|c|}{ Susceptible check } \\
\hline Morocco & & $80 \mathrm{~S}$ & $100 \mathrm{~S}$ & $80 \mathrm{~S}$ & $80 \mathrm{~S}$ \\
\hline
\end{tabular}

MS = moderately susceptible; $\mathrm{MR}$ = moderately resistant; $\mathrm{R}$ = resistant; - = not tested; 0 = no infection.

They are selected because they are promising lines and pipeline genotypes. 
High severity of stripe rust on standard differentials and other wheat lines in 1980s as well as in the recent studies confirmed that the rust is an endemic problem in the hills and high hills due to frequent changes of new pathotype [5]. Resistances shown by several differential lines possessing more than one gene or combination of genes could be an option to develop the rust resistant wheat varieties for the hills and high hills.

The change in reaction of the cultivar possessing Yr2 and $\operatorname{Yr} 9$ from 1980 to 2008 suggests that Pst population could have changed over that period. The most prevalent races during the mid 1980s were 7E150, 7E158 and 15E158 [15], and before that period, were some primitive races, like $2 \mathrm{EO}$ and $4 \mathrm{EO}$ [16-18]. The cultivar Annapurna-1 possessing $\operatorname{Yr} 9$ was resistant in 1980 [6], and it was recorded susceptible in 1997 due to change in the race of 465119 [19], but it was again resistant in 2007 and 2008. It is also suggested that most of the Veery's lines are heterogeneous, which shows different rust reactions at different times, especially on Annapurna-1 and Annapurna-3. On the other hand, Pasang Lhamu showed consistently resistant from 1989 till 2008, suggesting that this cultivar has other resistance genes in addition to Yr9. Since Pasang Lhamu has remained resistant to the rust over 20 years under severe rust epidemic conditions, it could be considered as a durable source of stripe rust resistance and useful for the hills and high hill wheat growing environments. This cultivar has been widely used in the breeding program. Similarly, Plant Pathology Division had tested wild emmer derivative (Triticum dicoccoides) to broaden the genetic base of wheat cultivars in Nepal $[8,20]$. The lines V763 and V879 were resistant to the rust and they have $T$. dicoccoides G-25 in their pedigree which carries $\operatorname{Yr} 15$ [21]. This gene was incorporated in high yielding disease susceptible wheat varieties, such as UP262, RR21, Triveni and Vaskar.

A number of advanced breeding lines and promising commercial cultivars developed in the last few years, proved resistant to the rust. This suggests that resistant germplasms are being introduced to wheat improvement program in Nepal. A few of these lines that originated from CIMMYT, Mexico possess minor genes based stripe rust resistant parents in their pedigree, which could be valuable sources of resistance in the hill and high hill regions. One of the examples is WK1204 released for the hills in 2007, which is resistant to the rust under this environment [5]. This cultivar got wider coverage within a short period using faster dissemination through participatory varietal selection (PVS) method. Soon after 2005's epidemic of the rust, wheat cultivar Gautam also emerged as a potential rust resistant wheat cultivar and seeds were extensively distributed to farmers in the rust prone area, though it was released for warmer area of Terai. During seed scarcity period, Gautam and WK1204 were proved as miracle cultivars and led to quick replacement of old susceptible ones in Nepal. Additionally, many other lines, such as WK1182, WK 1444, BL3235 and BL3503, were also promoted through extensive PVS method. Because of all these efforts, significant minimization of the rust was observed after 2007. This work of enhancing genetic diversity for the rust resistance in Nepal hills was further strengthened by the release of two more resistant varieties Gaura (BL3235) and Dhaulagiri (BL3503) in 2012. Further elite lines originating from CIMMYT and possessing minor genes could be valuable sources for resistance to the rust in the hills and high hills region in future.

There are important implications of development of new races or change in population structure of Pst in the hills of Nepal. Stripe rust present in the summer grown wheat, maturing in October and November in the hills, could move down to the lower hills, foot hills and eventually to the low-lands which are parts of the vast Gangetic Plains [22]. It is experienced that the early multiplication of the rust inoculum in Nepal directly affects wheat in India [23]. Since urediospores 
of the rust are carried over long distances, change in virulence in one country has epidemic effects in the other [7] and needs common strategies to tackle the problems. The extensive cultivation of the Veery 5 selection created a vulnerable situation, and stripe rust epidemic was recorded in the Middle East in 1990s and in Pakistan during and after 1994 [7]. The new Yr9 virulence caused heavy outbreak in India and Nepal during 1996 and 1997 [7, 19]. Therefore, it is important to monitor the virulence pattern of the rust in the hills and high hills belt of Nepal and identify sources of resistance. This may also help to develop common strategies, like increasing genetic diversity of varieties, race monitoring and increasing adult plant resistance to minimize the epidemics of the rust in the region [22, 24]. Faster seed delivery to farmers and researchers as demonstrated in case of Ug99 resistant wheat varieties can also be replicated for stripe rust resistant for quick management of rust [25].

\section{Conclusions}

Since there is little published information on the long-term monitoring of Pst in South Asia, the findings of this study is valuable to manage stripe rust in the subcontinent. Four genes (Yr5, Yr10, Yr15 and $\mathrm{YrSp}$ ) consistently showed resistance to the prevailing races. The gene $\operatorname{Yr} 9$ and $Y r 27$ in combinations with Yr18 were found effective. Other lines with combination of minor genes were also found effective. The genotypes Amadina, Kukuna, Tukuru, Kakatsi and Buck Buck have been widely used in breeding program. Resistant varieties WK1204, Gautam, Gaura and Dhaulagiri have wider adoption even at remote rust prone areas, which replaced susceptible varieties, increased genetic diversity for the rust resistance and ultimately enhanced food security in the country. Information on effective genes and resistant varieties could be helpful in developing stripe rust resistant wheat. The advanced breeding lines which are identified as resistant to the rust could be further tested for their agronomic performance and to release as commercial cultivars or use in the wheat breeding programs.

\section{Acknowledgments}

The authors are grateful to Nepal Agricultural Research Council (NARC) and Plant Pathology Division, National Agriculture Research Institute (NARI), Lalitpur, Khumaltar, Nepal for all cooperation extended during the research conduction. They are very thankful to CIMMYT, ICARDA and Plant Breeding Institute, Sydney, Australia, National Wheat Research Program, Bhairahwa, Nepal, Agriculture Botany Division, NARI, Lalitpur, Khumaltar, Nepal for providing germplasm for this study and all kinds of cooperation. The authors also would like to convey their thanks to Mr. Surath Pradhan, program coordinator of CIMMYT, Nepal and Santosh Sanjel, research assistant for their support in preparation of this manuscript. Finally, the authors are grateful to Mr. Manoj Sapkota, research assistant for making this paper in shape.

\section{References}

[1] Chatrath, R., Mishra, B., Ortiz-Ferrara, G., Singh, S. K., and Joshi, A. K. 2007. "Challenges to Wheat Production in South Asia.” Euphytica 157 (3): 447-56.

[2] Joshi, A. K., Mishra, B., Chatrath, R., Ortiz-Ferrara, G., and Singh, R. P. 2007. "Wheat Improvement in India: Present Status, Emerging Challenges and Future Prospects.” Euphytica 157 (3): 431-46.

[3] Nazari, K., Hodson, D., Yahyaoui, A., and Singh, R. 2009. "Field Based Pathogenicity Survey and Likely Migration Pattern of Wheat Yellow Rust in CWANA.” In Abstract of the 4th Regional Yellow Rust Conference for Central and West Asia and North Africa, 6.

[4] Ziyaev, Z. M., Sharma, R. C., Nazari, K., Morgounov, A. I., Amanov, A. A., Ziyadullaev, Z. F., Khalikulov, Z. I., and Alikulov, S. M. 2011. "Improving Wheat Stripe Rust Resistance in Central Asia and the Caucasus.” Euphytica 179 (1): 197-207.

[5] Thapa, D. B., Mudwari, A., Basnet, R. K., Sharma, S., Ortiz-Ferrara, G., Sharma, B., and Murphy, K. 2009. "Participatory Varietal Selection of Wheat for Micro-nitches of Kathmandu Valley.” J. Sustainable Agric. 33 (7): 745-56.

[6] Karki, C. B., and Sharma, S. 1990. "Wheat Disease 
Report 1989-90.” In Proceedings of the Thirteen National Winter Crops Seminar (Wheat Report), 269-88.

[7] Saari, E. E. 1996. "The Current Yellow Rust Situation in South Asia 1995.” In Proceedings of Wheat Research Report National Wheat Research Program, 12-7.

[8] Karki, C. B., and Karki, P. B. 1996. "Wheat Disease Report 1994/95, Nepal.” In Proceedings of Wheat Research Report, National Wheat Research Program, 269-88.

[9] Karki, C. B., Sharma, S., and Duveiller, E. 2004. "Yellow Rust of Wheat in Nepal: An Overview.” Presented at the Second Regional Yellow Rust Conference, Islamabad, Pakistan, March 22-26, 2004.

[10] Upreti, R. P., and Karki, C. B. 1999. "Effect of Fungicides on Yellow Rust, Grain Yield and Thousand Kernel Weight of Wheat.” Nepal Agric. Res. J. 3: 107-9.

[11] Witcombe, J. R., Joshi, A., Joshi, K. D., and Sthapit, B. R. 1996. "Farmer Participatory Crop Improvement: Varietal Selection and Breeding Methods and Their Impact on Biodiversity.” Expl. Agric. 32 (4): 445-60.

[12] Sharma, S. 2008. "Identification of Low Cost Technology on Yellow Rust Spore Preservation and Multiplication.” Nepal J. Plant Sci. 2: 51-4.

[13] Danial, D. L., and Broers, L. H. M. 1994. "Response of Different Selection Criteria on the Type of Resistance in Wheat to Yellow Rust." In Aspects of Durable Resistance in Wheat to Yellow Rust, edited by Danial, D. L. The Netherlands: Wageningen Agricultural University, 79-90.

[14] Sharma, S., Louwers, J. M., Karki, C. B., and Snijders, C. H. A. 1995. "Postulation of Resistance Genes to Yellow Rust in Wild Emmer Wheat Derivatives and Advanced Wheat Lines from Nepal.” Euphytica 81 (3): 271-7.

[15] Louwers, J. M., Van Silfhout, C. H., and Stubbs, R. W. 1992. Race Analysis of Yellow Rust in Wheat in Developing Countries. Report 1090-92, Research Institutes for Plant Protection, the Netherlands (IPO-DLO).

[16] Karki, C. B. 1980. Evaluation of Nepalese Wheat and Barley Varieties in the Seedling Stage on Their Resistance to Yellow Rust. Research Report of the Research Institute for Plant Protection (IPO), Wageningen, the Netherlands.
[17] Karki, C. B., Sharma, S., and Duveiller, E. 2012. "Yellow Rust of Wheat in Nepal: An Overview.” In Meeting the Challenge of Yellow Rust in Cereal Crops, edited by Yahyaoui, A., and Rajaram, S. Aleppo, Syria: International Center for Agricultural Research in Dryland Area (ICARDA).

[18] Sharma, S., Ghimire, S. R., and Pradhanang, P. M. 1996. "Identification of Yellow Rust Races of Wheat in the Western Hills of Nepal." In Proceedings of Wheat Research Report of National Wheat Research Program, 339-44.

[19] Sharma, S. 2001. "Yellow Rust Disease of Wheat in Western Hills of Nepal." In Proceedings of the 1st Society of Agricultural Scientist, Nepal Agricultural Research Council Convention, 170-5.

[20] Karki, C. B. 1999. "Wild Emmer Wheat as Potential Source of Yellow Rust and Loose Smut Resistance and High Grain Yield Potential.” In Proceedings of National Conference on Wild Relatives of Cultivated Plants in Nepal, 167-76.

[21] Gerechter-Amitai, Z. K., Van Silfhout, C. H., Grama, A., and Kleitman, F. 1989. "YR15-A New Gene for Resistance to Stripe Rust Puccinia striiformis in Triticum dicoccoides Selection G25.” Euphytica 43: 187-90.

[22] Bahadur, P., Karki, C. B., Bimb, H. P., Alam, K. B., and Dubin, H. J. 1994. "An Attempt to Monitor Wheat Rust in the South Asian Countries through Trap Nursery." Cereal Rust and Powdery Mildews Bulletin 22: 15-20.

[23] Joshi, L. M., Shrivastava, K. D., and Singh, D. V. 1985. "Monitoring Wheat Rust in Indian Sub-continent." Proc. of Plant Sciences 94 (2): 387-406.

[24] Nagarajan, S., Bahadur, P., and Nayar, S. K. 1984. "Contemplating the Brown Rust Resistance ( $\mathrm{Lr}$ genes) to Mitigate the Spread of Puccinia recondia f. sp. tritici." Indian Phytopath. 30: 490-7.

[25] Joshi, A. K., Azab, M., Mosaad, M., Moselhy, M., Osmanzai, M., Gelalcha, S., Bedada, G., Bhatta, M. R., Hakim, A., Malaker, P. K., Haque, M. E., Tiwari, T. P., Majid, A., Jalal Kamali, M. R., Bishaw, Z., Singh, R. P., Payne, T., and Braun, H. J. 2011. "Delivering Rust Resistant Wheat to Farmers: A Step towards Increased Food Security.” Euphytica 179 (1): 187-96. 